\title{
Response of Fuel Subsidy Removal as Sustainable Transport Policy (Case Study: Workers in Jakarta Metropolitan Area)
}

\author{
Octaviani Ariyanti \\ Office of the Authority Port Inland of Gilimanuk, Ministry of Transportation, Denpasar, INDONESIA \\ octavianiariyanti@yahoo.com \\ Samuel Petros Sebhatu \\ Karlstad Business School, Karlstad University, Karlstad, SWEDEN \\ samuel.sebhatu@kau.se
}

\begin{abstract}
Motorization in urban areas contributes several problems such as congestion, accidents, gas emissions, noises, and infrastructure breakage. Meanwhile, most of the developing countries cannot overcome such growth activities, as well as in Jakarta. By December 2013, Vice Governor of Jakarta proposes fuel subsidy removal policy as one of sustainable transport policy. This study is intended to understand and investigate how fuel subsidy removal policy scenarios $(25 \%, 50 \%$, and $100 \%)$ in Jakarta affects travelers' behavior and analyze such policy to support sustainable transport by using qualitative research methodology. Interviews and questionnaires survey is conducted to workers in Jakarta, which includes ranking scale question for traveler response options. The result shows that half of the respondents are not affected and will only respond to fuel price increasing at IDR 31,400 for gasoline price and IDR 26,300 for ADO (Auto Diesel Oil). Moreover, there is a tendency of respondent's to the response by changing their travel mode choices into more fuel efficient private vehicle.
\end{abstract}

Keywords: sustainable transport, transport policy, fuel subsidy, removal, fuel policy

\section{INTRODUCTION}

Travel activities and urbanization have evolved in line with the economic growth which is followed by the increasing number of motorization in many countries. In which, the motorization in urban areas causes many problems, and its impacts become the second contributor to environmental issues, both locally and globally as climate change. It is expected as the amount of private vehicle ownership in developing countries raises continuously as people tend to travel with their ownership of private vehicle and unenthusiastic to use public transport in major cities (Susilo, et al., 2007). The same problem also occurs in Jakarta, the Indonesian capital, which has not been able to decipher the congestion problem due to the imbalance between the ratio of the number of vehicles and the number of roads.

During the new leadership, Jakarta governments are going to reform several policies to address the transportation issues in Jakarta. As stated by the vice governor of Jakarta with his revealed plans to carry out the elimination of subsidized fuel in Jakarta area in order to reduce the number of private vehicle users in Jakarta (Suryanto, 2013), which is not in line with support sustainable transportation scheme. Among the 33 provinces in Indonesia, Jakarta becomes a province with the highest intake of subsidized fuel within 38 percent of total fuel energy consumption (BPH Migas, 2012). In 2014, the Indonesian state budget spends of IDR 131.2 trillion (U.S. \$ 11,528 billion) for fuel (Ministry of Finance, 2014). Globally, energy subsidies reached about \$ 544 billion in 2012 (IEA, 2013). The cost of subsidies for fuel places a heavy load on the limited public resources. Fuel subsidy policy affects the sustainable development policy as spending such amount on fossil-fuel subsidies give lost opportunity for development, in terms of social spending for any other sectors of society (Merrill, 2014), including sustainable transport. Therefore, in order to improve such strategy efforts, it is necessary to identify related how effective these policies will influence travelers' behavior to choose the mode of transport.

\section{THEORETICAL FRAMEWORK}

Recent years, many articles, reports, and publications were contributing a great consideration in sustainable issues. The notion of sustainability is embedded to develop responsiveness as most of human activities causing significant impacts to environmental. In such case, sustainability needs to manage integrated analysis and planning from any sectors, authorities and clusters to forestall and manages problems before 
the crises getting worse (Litman \& Burwell, 2006). Sustainable development is the hurdle of delivering efficiency and quality management where the service innovation is required (Sebhatu, et al., 2011). The potential sustainable travel results by allowing the coordination of transport actions in the context of land development. The combination of land use and transportation lies at the heart of the strategy. The transport network presents the key to urban formation. It is also based on achieving a high level of sustainable approachability by providing high-quality walking and cycling path (Curtis, 2008).

Policy makers have implemented most effort as barriers at reducing the need for travel to achieve sustainable transport towards technological, economic, and planning interventions (Banister, 2003). As private vehicle consumes more in nonrenewable resources than any other transport forms, therefore, most public policy concern on to give an action on private vehicle reduction directly. Goldman \& Gorham (2006) investigated the sustainable urban transport can be strongly achieved if sustainable transport policy considers of broader systems in transportation. Goldman \& Gorham (2006) in their research, stress that sustainability is a matter about innovations in a dynamic context.

Transport policies also create other mode choices by enhancing quality and attractiveness. For example, public transit supply is generally less cost, reliable, convenience and good quality in Western Europe; and also there are safe walking and cycling path provided for pedestrians and cyclists (Buehler, 2010). Transport policy measures can be employed to achieve a reduction of the negative effects of private vehicles usages, through the changes of travel behavior. Such transport policy measure commonly implemented in four types, i.e. legal policies, economic policies, measures changing the physical context, and informational/educational measures. Besides, the acceptability of transport policy measures has to be predicted well, as public's might response the transport policy measures negatively or positively. It was found that pull measures tend to be more acceptable than push measures.

\subsection{Fuel Policy}

Fuel policy, which was originally designed for economic purposes, also gave a positive impact on the environment. Such policy is important for the environment because more than $50 \%$ of the total carbon emissions come from vehicle fuel (Sterner, 2007). There have been several researchers during 1990s fuel price, yet, mostly focused on elasticity which is determined to be inelastic for short term. For instance, Goodwin, et al. (2004) revised several empirical studies in the meantime from 1990 around the world and stated findings that an increasing fuel price around $10 \%$ will reduce $1 \%$ in vehicle miles traveled and $2.5 \%$ in fuel consumption. In addition, the same study also stated that the same percentage of increasing fuel price will produce $1.5 \%$ increase in fuel efficiency of vehicles and reduce less than $1 \%$ in net vehicle ownership. It is assumed that the results of the increase in fuel price will trigger private vehicles' users for more efficient use of fuel through technical improvements to their vehicles and change their driving behavior. This evidence explains the reason of why when fuel prices increased, the decreasing number of fuel consumption tends to be larger than the decrease in traffic volume.

\subsection{Fuel Subsidy}

Fossil fuel subsidies are one of the vital policies to policy-makers and public opinion, so it is important to define the policy carefully, where its application contributes directly to climate change. In 2012, the consumption of fossil fuel subsidies around the world alone reached about $\$ 544$ billion. Granting fuel subsidies also encourage the consumption of fossil fuels and excessive, resulting in billions of tons of carbon emissions per year. The OECD predicted that by removing fuel subsidies by 2020 , there will be the reduction in GHG emissions around $10 \%$ by 2050 , which could significantly contribute to limit global warming issue (Burniaux \& Chateau, 2011). Fuel subsidy policy affects the sustainable development policy as spending such amount on fossil-fuel subsidies give lost opportunity for development, in terms of social spending for any other sectors of society (Merrill, 2014).

There are several countries successfully implement the reform of fuel subsidy policy, for example, Brazil, Philippine, and Turkey. Brazil government adopted a gradual approach to eliminating fuel subsidies. The Philippines started the liberalization of energy prices as part of a broader deregulation of the energy sector in 1996 with a strong political will, planning, and building an effective consensus. Turkey initiated energy sector deregulation and price liberalization program in the early 1990s (Anand, et al., 2013).

\subsection{Fuel Policy in the United Kingdom, United States of America, and Australia}

In United Kingdom (UK), Goodwin, et al (2004) investigated the price and income elasticity to transport activity. The price effect is estimated to provide a dynamic effect and predicted that if the real 
price of fuel rose by $10 \%$ and remained at that level, the traffic volume and the volume of fuel consumption will show the decline both for long-term and shortterm. Graham \& Glaister (2004) not only analyzed price elasticity and established the result that germination in fuel prices influence more on fuel consumption than on the number of kilometers driven, but also argued that people tend to make fewer trips, but travel much shorter distances. Influencing car use by policy measures is easier than influencing car ownership. Car use reacts more vigorously and more instantly to prices and is less resistance to change (Dargay, 2007).

In Australia, considering Win-Win Transportation Solutions that is one of policy strategy, where market changes, it will increase overall transport system efficiency (Litman, 2007), for example a carbon tax within increasing fuel tax gradually and predictably is the most efficient energy conservation and emission reduction strategy (Litman, 2011). Governments need to conduct a national communications program to make people aware of the effects related to the oil consumption and its impact on reducing the vulnerability of oil (Robinson, et al., 2005).

Bomberg \& Kockelman (2007) conducted a study in Austin, Texas (United States of America) and investigate about how travelers respond to gas prices spike in September 2005 within a survey of over 500 residents. The response during and after the spike and found that respondents tend to react by managing their travel as a result of high prices. Bomberg \& Kockelman (2007) found that travelers are most likely to respond by reducing their overall driving caused $75 \%$ reduction in short-term gasoline demand for the reduction of vehicle miles traveled.

In general, it could be stated while the fuel policy implemented in those countries, it will increase overall transport system efficiency. Such reduction may be achieved by changing modes, trip chaining, and driving style. Therefore, Governments need to conduct a national communications program to make people aware of the effects related to the oil consumption for supporting the national fuel policy.

\section{DATA COLLECTION}

The primary data of this research is obtained from interview survey with questionnaires in order to gather the response toward fuel subsidy removal policy in Jakarta. First, the interview is conducted to worker respondents who own automobile and motorcycle. This study uses e-mail interviews, which are commonly used by researcher as a digital era is spread used today and also employ online interview using social media. Using purposive sampling as dominant strategy in qualitative research and to gather in depth and rich information (Patton, 1990), hence, the interview is conducted to 19 persons, with 7 as car users and 12 motorcycle users. Qualitative interviewing utilizes open-ended questions that allow for individual variations, with a list of questions or general topics are made for interview guide to find out the preference of using subsidized fuel and the behavior after the policy implemented.

Meanwhile, questionnaire surveys were conducted by online survey in April to May 2014 for workers in Jakarta, altogether, 179 respondents; which are 135 private vehicle users and 44 non-private vehicle users. Data collection was conducted for workers in Jakarta who live in Jakarta or surrounded city that is Bogor, Tangerang, Bekasi, and Depok. A survey with questionnaires is conducted after interviewed done, and the questions will be adaptable based on interview result. The questionnaire survey consists of 26 questions aiming to capture how travelers will response the fuel subsidy removal policy in Jakarta. In addition, there are three scenarios of how fuel subsidy will be implemented $(25 \%, 50 \%$, or $100 \%$ removal) which proposes six stated preference options about how traveler will give a response, and the respondents are asked to rank from one to six based on their primary consideration.

\section{EMPIRICAL STUDY}

\subsection{The Overview of Existing Transportation in Jakarta}

Transportation problems in Jakarta are getting worse, which is predicted become total gridlock in 2014 if there is no significant action to solve such problem (Susantono, et al., 2011). Jakarta has a policy about macro transport master-plan in order to handle transport system and traffic congestion, which is established in the Regional Regulation of Jakarta Province No. 103/2007. This policy is designated to improve the efficiency and effectiveness of mobility, thus, it will simultaneously give positive impacts, such as reducing pollution, operational cost, and improving transportation system. To date, the new Government has renewed the policy and targeted to generate an efficient, integrated, and comprehensive road network and system; thus, $60 \%$ (sixty percent) of residents targeted will travel by public transport and increase the average speed of $35 \mathrm{~km} / \mathrm{hour}$ at minimum. Development of Public Transport in Jakarta becomes one of the purposes of the city government in Jakarta Transportation Master Plan to 
reduce congestion. Public transport development in Jakarta Master Plan is divided into several kinds of modes, i.e. BRT Trans Jakarta, Commuter Line, and MRT/Subway.

\subsection{Fuel Policy}

Fuel subsidy system in Indonesia considered no longer sustainable as such system tends to encourage overconsumption and inefficient use of fuel and contort the efficient allocation of resources that indicate totally different things with sustainable notion (Widodo, et al., 2012). The state budget for increased spending on energy subsidies in the 2008-2013 time frame of IDR 223 trillion in 2008 and became IDR 299.8 trillion in the revised budget, in 2013. Meanwhile, subsidized fuel volume consumption in recent years tended to increase. Initially, in 2008, the realization of subsidized fuel consumption reached 38.2 million kiloliters; in 2012 reached 43.3 million kiloliters, and in 2013 reached 48.0 million kiloliters. Particularly in Jakarta, the use of subsidized fuel up to 3 million kiloliters/year and spend around IDR 12 trillion to finance the fuel subsidy. In Indonesia, the state budget for mass transit is still much smaller than the fuel subsidy. Therefore, the fuel subsidy policy encourages people to drive more with their private vehicle, which causes terrible effect in traffic conditions in Jakarta.

\section{RESULTS AND DISCUSSION}

\subsection{Removing Subsidized Fuel Matters in Indonesia}

From interviews, it was found that they tend to use their private vehicle as a primary mode choice for various reasons, those are time efficiency, high mobility, comfortable, cost efficiency, flexibility, good accessibility, and their bad experience using public transport. Similarly, with the interview results, the questionnaire survey also shows a significant number of respondents that feel their preferred choice is because of its time efficiency. Other reasons for their choices in travel modes are also showing a resemblance between interview results, such as cost efficiency, comfort, and safety. And that the average travel time 32.1 minutes and $18.5 \%$ of respondent's travel time is around 11 to 20 minutes. Meanwhile, a higher proportion of the respondents in travel cost is between IDR 201,000 - IDR 400,000 each month. Particularly, the reason of bad experience using public transport emerged in interviews, as Public Transport service in their opinion is unreliable, uncomfortable both in bus and shelter, unsafe, insecure, and costly. According to the respondents, they are not usually using public transport in travel to work. Only $22.2 \%$ of respondents are using Public Transport as their primary choice, while the other only use that for once a month $(36.3 \%)$, every 6 months $(25.2 \%)$, and never use $(16.3 \%)$.

Many issues need to be considered when enhancing links between sustainable public transport policy and fuel policy, especially fuel subsidy removal policy. Fuel policies can obliquely reduce the number of trips of private vehicle users, as the result of making efficiency of fuel expense (Goodwin, et al., 2004). The subsidy for those fuel price is progressively grown even bigger by the time and more convoluted state budget, yet, fuel subsidy scheme also discords with sustainable notion (Widodo, et al., 2012). In Jakarta Metropolitan area, the use of subsidized fuel up to 3 million kiloliters per year. Which is proven from questionnaire survey, it found that $48 \%$ of respondents are using subsidized fuel for the whole consumption. The same evidence is also convinced by interview result, which are 13 persons of 19 interviewers always use subsidized fuel for their private vehicle. There are four reasons explained by respondents of their preference using subsidized fuel. Most frequent answer of those reasons, about $43 \%$, is cost efficiency offered by such fuel price. Other reasons occur in the interviews are vehicle specification, no prohibition rule, and the distrust of the government's policy related to subsidy.

Accordingly, rather than wasting a big portion of National Budget only become wastage at traffic jam in Jakarta, produce more pollution and giving no beneficial through fuel subsidy; Government should reform the budget into another valuable sector, such as public transport improvement. Overall, there are various reasons and suggestions from interview result for implementing fuel subsidy removal, i.e. less restriction of private vehicle ownership tax, decentralized development which can reduce urbanization, and government need to coordinate policies with other regions and institutions.

Being asked about the opinion related to the effectiveness of Fuel Subsidy Removal policy, around $27 \%$ of respondents are neutral. Even though the equal proportion, around $21.79 \%$, are choosing "agree" and "disagree", yet, there is $41.34 \%$ respondents choose 'agree' or 'strongly agree' with the effectiveness of implementing such policy in Jakarta.

Besides the effectiveness opinion, respondents also questioned about expectation of Fuel Subsidy Reform to Public Transport in Jakarta, and it is found about 
$84.92 \%$ respondents answer with 'agree' or 'strongly agree', as can be seen in Figure 1.

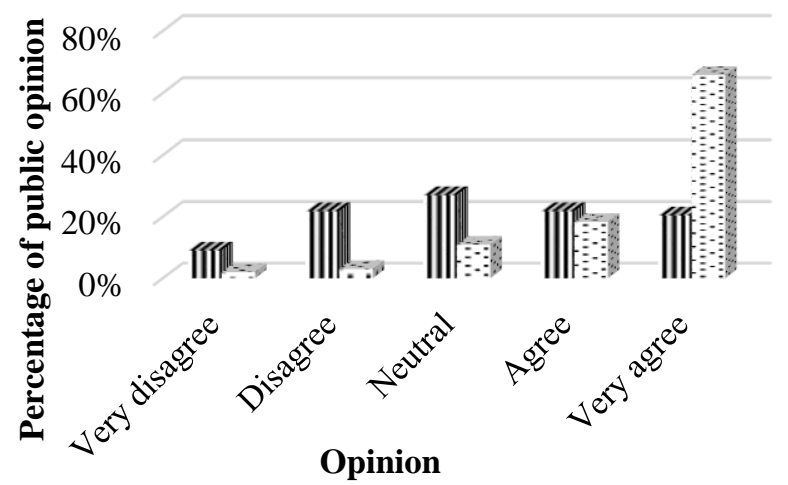

III Effectiveness of Fuel Subsidy Removal Policy
Implementation in Jakarta
Expectation of Fuel Subsidy Reform become
Development Fund of Public Transport in Jakarta

Figure 1.Public opinion of fuel subsidy policy.

\subsection{Fuel Subsidy Removal Policy Proposal}

The respondents were asked about how often they purchase subsidized fuel for their private vehicle and found that $48 \%$ of respondents are using subsidized fuel for the whole consumption. Further, the questionnaires are proposing 3 scenarios of Fuel Subsidy Removal policy that are $25 \%, 50 \%$, and $100 \%$ removal scenario. The result also found that $50 \%$ of the respondents say that they are not affected by such policy in every scenario. Only 5\% and $9 \%$ reported responding to scenario of $25 \%$ and $50 \%$ removal, while the rest $36 \%$ are treated with scenario of $100 \%$ removal. Meanwhile, the commuter from outside Jakarta area (Bogor, Depok, Tangerang, and Bekasi) are also showing the same pattern; with $43 \%$ of respondents not affected with any scenarios and another $43 \%$ are only affected with the full removal of subsidy scenario. Further questions are asked whether to know at what price the respondents will give any response to fuel policy. It found that they are concerned mostly to shift their travel behavior, only if the price of fuel price is above IDR 10,000/liter. The average rate for fuel price that might be considered to change it is around IDR 31,400 for premium price and IDR 26,300 for IDO each liter.

Another question also asked as the prediction of behavioral response questions addressed transportation related fuel subsidy removal. The behavioral questions were scored on ranking scales from 1 to 6 depends on their consideration of 6 stated preference response options. Regarding such responses from questionnaire toward Fuel Subsidy
Removal, high rank score from respondents is choosing to remain at the current residence, but followed by the changes of their travel mode choices to the more efficient private vehicle. The sustainable issue is also mattered, as it comes out from the second highest score is their preferences to shift into sustainable transport, such as using public transport, walking, and cycling, as can be seen in Figure 2. Similarly, the responses of the commuter from Bogor, Depok, Tangerang, and Bekasi are also showing that they tend to response the fuel policy within changing their private vehicles to more fuel efficient fleet.

As some researchers showed strong evidence that gasoline consumption is very affected by the price and income (Ariyanti, 2014), thus, a cross tab analysis was employed in this research by using these two variables. From the analysis using crosstab formula within household's income variable and fuel price preference, it shows that those with households' income from 2.5 million rupiahs, mostly only affected by the price over IDR 10,000/liter. In addition, some respondents with 5 million to 10 million rupiah households' income are mostly affected by third scenario and some other only response for fuel price around IDR 20,000 to IDR 30,000 per liter.

It illustrates that perhaps income might influence their response to fuel policy. Relating to income effects, Goodwin, et al., (2004) argued that the increase of income may lead car owners into the car market. In addition, the rising income can also affect inefficiency of the use of fuel. Such choices can also raise the numbers of multiple cars per driver (e.g. 'sports' vehicles) in wealthy countries while, in poorer countries/households, it may be more correlated with the first acquisition of cars by non-workers who typically use them less.

Litman (2011) also found that people's income determines travel behavior. For example, within the increasing incomes, owning and operating a car becomes affordable. In this research, the result shows that fuel subsidy removal policy does not effectively affect those with high-income households, thus, this policy will need to be supported by another policy since most of the travelers still have high income to cover fuel price even without any subsidy on it. For instance, their company should arrange supporting police to force them not driving their private vehicle to the working place. However, as Sterner (2007) stated that this issue makes policy makers hesitate since it only gives politicians a small chance for reelection, thus, they should think carefully and eager to make a good integrated policy. 


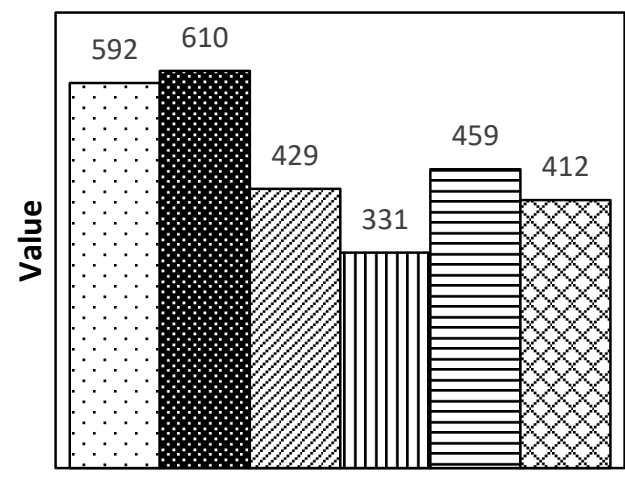

Stated Preference Responses
Remain at the current residence, with the shift to more sustainable modes of transport (public transport, walking, cycling)

$\mathbf{8}$ Remain at the current residence, with the shift to private vehicles with fuel efficient (smaller engine cars, motorcycles, electrical car)

$2 /$ Remain at the current residence, with shopping around to areas outside the policy for the best price of gasoline

II Move to the other areas outside settlement policy, without any changes of their mode choice of private vehicles

$=$ Move to residential location in the vicinity of the work area, without any changes of their mode choice of private vehicles

$\times$ Move to residential location in the vicinity of the work area, with the shift to more sustainable modes of transport (public transport, walking, cycling)

Figure 2. Responses to fuel policy

\section{CONCLUSION AND MANAGERIAL IMPLICATIONS}

Policy makers have to implement sustainable transport in the broader system towards innovations and value configuration within pull measures policy both locally and nationally. By generating transportation planning within sustainable paradigm- Therefore, it should carefully manage and reorganize policy options from locally and nationally. The planning should involve infrastructure, transportation facilities, and coordination with land development. Transport facilities development has to provide a high supply of public transit that is offering safety, reliable, less timeconsuming, and cheap; and also better facility in walking and cycling path. Meanwhile, other policies should be considered by the government to create inconvenient policies for car users, such as higher taxes, higher parking cost and limited supply, fewer urban roads, lower speed limits, and traffic calming of neighborhoods. Higher taxes for fuel can be implemented as a continuation of fuel subsidy removal policy.

Referring to behavioral questions in questionnaire survey, it shows that respondents tend to change their travel mode choices into more efficient private vehicle. Therefore, the government should work hard to improve the welfare of the community, especially to fix most of the transport sector to generate economic value. One effort that can be taken is to allocate transportation subsidies for public transportation since the fuel subsidy is increasingly burdened the national budget. Further, it should also involve coordination with land development. Particularly, improvement for fuel policy can be added higher taxes for fuel to continue fuel subsidy removal policy.

\section{REFERENCES}

Anand, R. et al., 2013. The Fiscal and Welfare Impacts of Reforming Fuel Subsidies in India. International Monetary Fund, Issue 13.

Ariyanti, O., 2014. Responses Of Fuel Subsidy Removal As Sustainable Transport Policy, Yogyakarta: Master Thesis, Department of Civil and Environmental Engineering, Universitas Gadjah Mada.

Banister, D., 2003. Sustainable Transport and Public Policy. Transportation Engineering Planning Encyclopaedia of Life Support Systems (EOLSS).

Bomberg, M. \& Kockelman, K. M., 2007. Traveler Response to the 2005 Gas Price Spike. Washington, DC.

BPH Migas, 2012. Pembatasan Konsumsi BBM Bersubsidi. [Online]

Available at: $\quad$ www.bphmigas.co.id [Accessed 8 March 2014].

Buehler, R., 2010. Transport Policies, Automobile Use, and Sustainable Transport: a Comparison of Germany and the United States. Journal of Planning Education and Research, 30(1), pp. 76-93.

Burniaux, J. M. \& Chateau, J., 2011. Mitigation Potential of Removing Fossil Fuel Subsidies: a General Equilibrium Assessment, OECD Publishing.

Curtis, C., 2008. Planning for Sustainable Accessibility: The Implementation Challenge. Tranport Policy, 15(2), pp. 104-112.

Dargay, J., 2007. The effect of prices and income on car travel in the UK. Transportation Research Part A: Policy and Practice, 41(10), pp. 949-960. 
Goldman, T. \& Gorham, R., 2006. Sustainable Urban Transport: Four Innovative Directions. Technology in Society, XXVIII(1), pp. 261-273.

Goodwin, P., Dargay, J. \& Hanly, M., 2004. Elasticities of Road Traffic and Fuel Consumption with Respect to Price and Income: a Review. Transport Reviews, 24(3), pp. 275-292.

Graham, D. J. \& Glaister, S., 2004. Road Traffic Demand Elasticity Estimates: A Review. Transport Reviews, 24(3), pp. 261-274.

IEA, 2013. Redrawing the Energy Climate Map World Energy Outlook Special Report.

Litman, T., 2007. Win-Win Transportation Emission Reduction Strategies. [Online] Available at: www.vtpi.org/wwclimate.pdf

Litman, T., 2011. Changing Vehicle Travel Price Sensitivities: The Rebounding Rebound Effect. [Online]

Available at: www.vtpi.org/VMT Elasticities.pdf

Litman, T. \& Burwell, D., 2006. Issues in Sustainable Transportation. International Journal of Global Environmental Issues, 6(4), pp. 331-347.

Merrill, L., 2014. Reform of Fossil-fuel Subsidies: Nordic Cooperation on Fossil-fuel Subsidy Reform in Developing Countries: Assessing Options and Opportunities, Copenhagen.

Ministry of Finance, 2014. Financial Note and State Budget 2014. [Online] Available at: http://www.anggaran.depkeu.go.id/dja/acontent/NK\% 202014.pdf

Nidumolu, R., Prahalad, C. K. \& Rangaswami, M. R., 2009. Why Sustainability is Now the Key Driver of Innovatio.
Patton, M. Q., 1990. Qualitative Evaluation and Research Methods. 2nd Edition ed. Newbury Park, California: Sage Publications, Inc..

Robinson, B. W., Fleay, B. J. \& Mayo, S. C., 2005. The Impact of Soil Depletion on Australi. pp. 19-20.

Sebhatu, S. P., Enquist, B., Johnson, M. \& Gebauer, H., 2011. Sustainability and Innovating ValueConfiguration Spaces for Innovative Public Transit Service.

Sterner, T., 2007. Fuel taxes: An important instrument for climate policy. Energy Policy, 35(6), pp. 31943202 .

Suryanto, 2013. Ahok: subsidi BBM ibarat usus buntu. [Online]

Available at:

http://www.antaranews.com/berita/410252/ahok-

subsidi-bbm-ibarat-usus-buntu

[Accessed 8 March 2014].

Susantono, B., Santosa, W. \& Budiyono, A., 2011. Kepemilikan Kendaraan dan Pola Perjalanan. Jurnal Transportasi, 11(3).

Susilo, Y. O., Joewono, T. B., Santosa, W. \& Parikesit, D., 2007. A Reflection of Motorization and Public Transport in the Jakarta Metropolitan Area: Lessons Learned and Future Implications Towards Better Transportation Development in Developing Countries. Dalian, China, Eastern Asia Society of Transportation Studies, Eastern Asia Society of Transportation Studies.

Widodo, T., Sahadewo, G. A., Setiastuti, S. A. \& Chaerriyah, M., 2012. Impact of Fuel Subsidy Removal on Government Spending. 
[this page intentionally left blank] 